\title{
Heat Response of Global Vegetation Biomes to Ongoing Climate Warming Based on Remote Sensing
}

\author{
Fei $\mathrm{Li}^{1, *}$ and Xiaoqiang Zhang ${ }^{1,2, *}$ \\ 1 Key Laboratory of Watershed Geographic Sciences, Nanjing Institute of Geography and Limnology, \\ Chinese Academy of Sciences, Nanjing 210008, China \\ 2 Key Laboratory of Environmental Engineering of Jiangsu Province, Jiangsu Provincial Academy of \\ Environmental Science, 167 North Jiangdong Road, Nanjing 210036, China \\ * Correspondence: fli@niglas.ac.cn (F.L.); dr.xqzhang@gmail.com (X.Z.)
}

Received: 25 July 2017; Accepted: 6 September 2017; Published: 9 September 2017

\begin{abstract}
Research is needed by global change scientists on how global vegetation biomes respond to ongoing climate warming. To address this issue, we selected study sites with significant climate warming for diverse vegetation biomes, and used global gridded temperature and remote sensing data over the past 32 years (1982-2013). The results suggested that climate warming in areas above approximately $60^{\circ} \mathrm{N}$ is relaxing the heat-constraints on vegetation activity, thus promoting plant growth; whereas, in mid to low latitude areas, ongoing climate warming probably imposes negative impacts on vegetation biomes through drought and heat stress. Understanding these potential effects is important for planning adaptation strategies to mitigate the impacts of climate warming, particularly for agro-ecosystems.
\end{abstract}

Keywords: global vegetation biomes; climate warming; heat responses; remote sensing

\section{Introduction}

Over the three decades since the 1980s, the earth has experienced significant ongoing climate warming, as well as a greening trend [1-6]. Interestingly, both are associated with human-induced elevation of atmospheric $\mathrm{CO}_{2}$ concentrations [2,4]. But what are the interactions between climate warming and earth greening? Earth greening implies that the capacity of the biospheric carbon pool is being boosted because of enhanced vegetation photosynthetic activity [7], which might be expected to mitigate the magnitude of climate warming and its associated negative effects on the earth system $[1,3]$. On the other hand, climate warming directly impacts the dynamics of the terrestrial vegetation biomes by increasing the frequency, duration and severity of drought and heat stress [8-11], while other studies have suggested that climate warming tends to relax temperature constraints for plant growth $[12,13]$. Many studies assume that plants have an optimal threshold for growth and reproduction [14], suffering cold stress when temperatures are below this threshold, and heat stress when above [15]. Accordingly, we can deduce that when the in-situ temperature is suboptimal, climate warming may relax the temperature constraint for plant metabolism and promote its growth, while supraoptimal temperature conditions and the accompanying rise in the vapor pressure deficit and evaporation may damage the plant's cellular tissues $[8,16,17]$. Here, we ask: what have been the responses in diverse vegetation biomes to ongoing recent climate warming? The objective is to provide insight into these issues through exploring vegetation behavior in representative warming places across diverse global vegetation biomes.

\section{Materials and Methods}

The dynamics in global vegetation biomes over the time period from 1982 to 2013 were monitored by an improved Normalized Difference Vegetation Index (NDVI3g) data set [18]. This NDVI3g time 
series was produced by Advanced Very High Resolution Radiometer (AVHRR) instruments with a 15-day maximum-value composite (MVC) NDVI from July 1981 through December 2013 at $8 \mathrm{~km}$ resolution. We obtained this data set from the Ecological Forecasting Lab at the NASA Ames Research Center (http:/ / ecocast.arc.nasa.gov/data/pub/gimms/). World vegetation biomes were mapped at 1 $\mathrm{km}$ resolution Moderate-resolution Imaging Spectroradiometer (MODIS) land cover data (MOD 12Q1), openly available through NASA's LAADS/DAAC system (https:/ /adsweb.nascom.nasa.gov/). These biomes comprised evergreen needleleaf forest (ENF), evergreen broadleaf forest (EBF), deciduous needleleaf forest (DNF), deciduous broadleaf forest (DBF), mixed forests (MF), shrublands (SHR), woody savannas (WSA), savannas (SAV), grassland (GRA) and croplands (CRO) as defined by the classification system of the International Geosphere-Biosphere Program (IGBP). Global $0.5^{\circ}$-gridded monthly air temperature data (V4.01) for 1982-2013, generated by the Center for Climatic Research Department of Geography, University of Delaware (https: / /www.esrl.noaa.gov/psd/data/gridded/ data.UDel_AirT_Precip.html), were used to identify representative warming places.

To explore the interaction between climate warming and vegetation biome activity at an inter-annual time scale, the 15-day MVC NDVI values were summarized by selecting the maximum value for each month and then averaging these monthly NDVI values, along with monthly air temperatures, to yearly NDVI and mean annual temperature (MAT), respectively. Representative warming places were identified by a two-step procedure that first selected places with a significant positive MAT trend (that is a positive linear trend with $p<0.01$ ). Their increase in MAT (+MAT) was then calculated, and study sites for the various vegetation biomes were selected from within the 90th percentile of the frequency distribution of + MAT. These procedures were designed to select sites with a magnified effect of climate warming on vegetation activity.

\section{Results}

Since the 1980s, areas with significant warming have covered approximately $40 \%$ of the earth's landmass (Figure 1). Areas of +MAT less than $0.5{ }^{\circ} \mathrm{C}$ accounted for $<5 \%$, while $>95 \%$ of climate warming areas had increases $>0.5^{\circ} \mathrm{C}$. For the southern hemisphere, the +MAT varied from 0.5 to $1.5^{\circ} \mathrm{C}$, and a considerable area had increases of $0.5-1.0^{\circ} \mathrm{C}$. In contrast to the latitude band $0-40^{\circ}$ $\mathrm{S}$, the +MAT for $0-40^{\circ} \mathrm{N}$ varied from 0.5 to $>2.5^{\circ} \mathrm{C}$, and a considerable area had increases $>1.0^{\circ} \mathrm{C}$. It should be noted that the most significant warming mainly occurred in non-vegetated areas located in Chad, Saudi Arabia and Iran. For the latitude band $>40^{\circ} \mathrm{N}$, most areas also experienced significant climate warming with +MAT varying from 1.5 to $>2.5^{\circ} \mathrm{C}$, and noticeably, areas of $>60^{\circ} \mathrm{N}$ had increases $>2.5^{\circ} \mathrm{C}$. Overall, the rate of climate warming progressively increases from the southern hemisphere to the mid-low latitude region of the northern hemisphere, and then to the high-latitude region of the northern hemisphere.

Under the classification system of the IGBP and MODIS land cover products, the largest biome of the earth is grassland (WSA, SAV and GRA), with an area accounting for $27.74 \%$, followed by forest $(21.45 \%)$, shrub (19.96\%), and crop (8.5\%) (Table 1). Over the past three decades, the overall +MAT for vegetation biomes is $0.74{ }^{\circ} \mathrm{C}$ for shrub, $0.57^{\circ} \mathrm{C}$ for grasslands, $0.49{ }^{\circ} \mathrm{C}$ for crop, and $0.38{ }^{\circ} \mathrm{C}$ for forest. For our selected study sites (Figure 2), those within the 90th percentile of the increment of MAT, the + MAT is $>3.10{ }^{\circ} \mathrm{C}$ for GRA, $>2.84{ }^{\circ} \mathrm{C}$ for SHR, $>2.65^{\circ} \mathrm{C}$ for ENF, $>2.11{ }^{\circ} \mathrm{C}$ for DNF, $>2.04{ }^{\circ} \mathrm{C}$ for CRO, $>1.95{ }^{\circ} \mathrm{C}$ for WSA, $>1.88{ }^{\circ} \mathrm{C}$ for SAV, $>1.82{ }^{\circ} \mathrm{C}$ for DBF, $>1.76{ }^{\circ} \mathrm{C}$ for $\mathrm{MF}$, and $>1.53{ }^{\circ} \mathrm{C}$ for EBF (Table 1 ). 


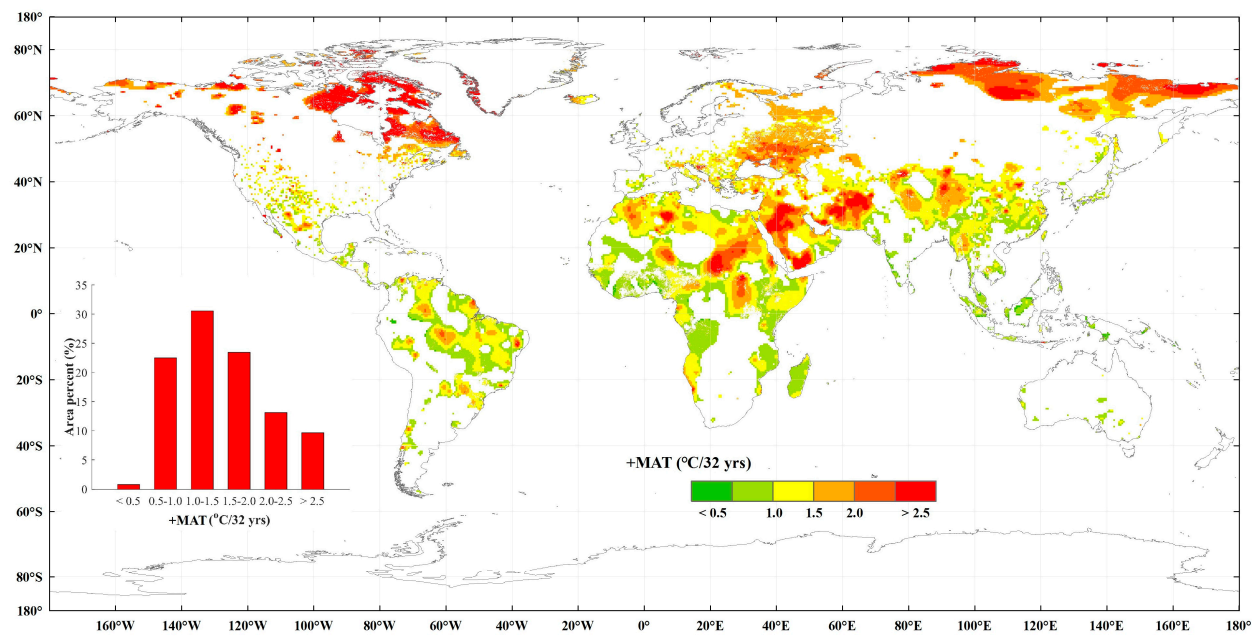

Figure 1. Increment of mean annual temperature (+MAT) from 1982-2013 at the global scale (increments significant at $p<0.01$ only).

Table 1. Statistics of area, area percent, + MAT, and + MAT at the 90th percentile for various vegetation biomes at the global scale.

\begin{tabular}{ccccc}
\hline Biome & Area $\left(\mathbf{m i l l i o n} \mathbf{~ k m}^{\mathbf{2}}\right)$ & Area Percent $(\mathbf{\%})$ & +MAT $\left({ }^{\circ} \mathbf{C}\right)$ & +MAT at 90th Percentile $\left({ }^{\circ} \mathbf{C}\right)$ \\
\hline ENF & 4.82 & 3.51 & 0.28 & 2.65 \\
EBF & 10.34 & 7.52 & 0.47 & 1.53 \\
DNF & 2.37 & 1.72 & 0.39 & 2.11 \\
DBF & 1.44 & 1.05 & 0.37 & 1.82 \\
MF & 10.52 & 7.65 & 0.38 & 1.76 \\
SHR & 27.43 & 19.96 & 0.74 & 2.84 \\
WSA & 10.40 & 7.57 & 0.40 & 1.95 \\
SAV & 7.82 & 5.69 & 0.62 & 1.88 \\
GRA & 19.90 & 14.48 & 0.69 & 3.10 \\
CRO & 11.68 & 8.50 & 0.49 & 2.04 \\
\hline
\end{tabular}

ENF: evergreen needleleaf forest; EBF: evergreen broadleaf forest; DNF: deciduous needleleaf forest; DBF: deciduous broadleaf forest; MF: mixed forests; SHR: shrublands; WSA: woody savannas; SAV: savannas; GRA: grassland; CRO: croplands.

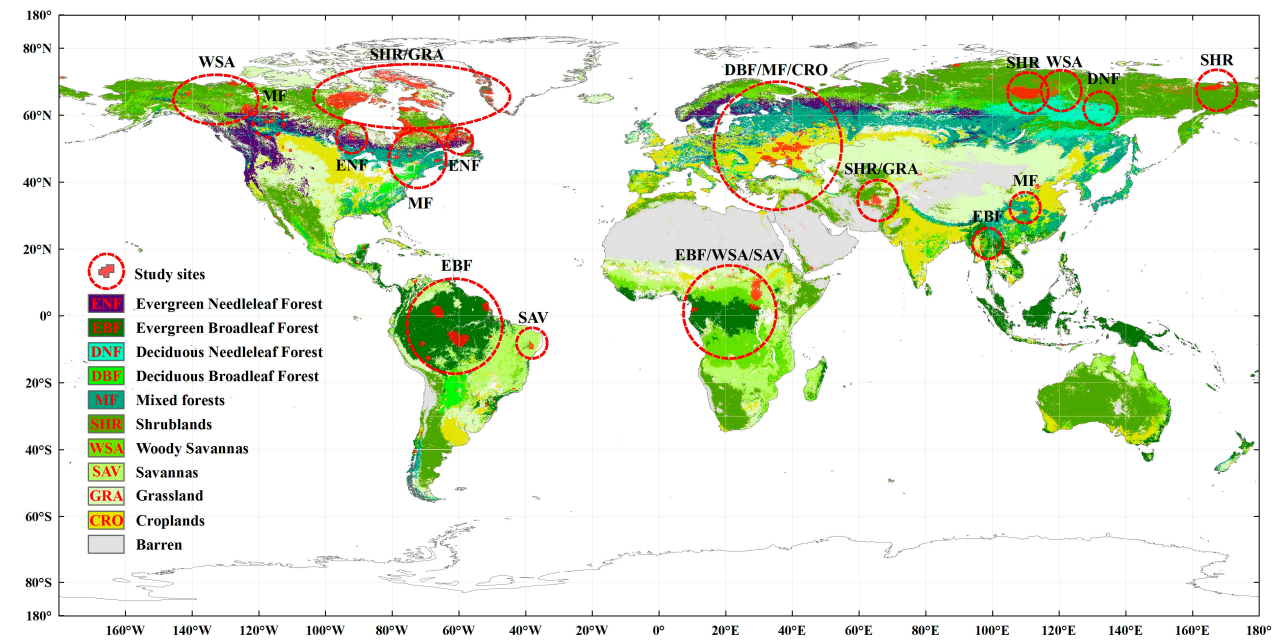

Figure 2. Study sites for the various vegetation biomes, all identified within the 90th percentile of the increment of MAT (+MAT). 
The response of vegetation to climate warming varied among biomes (Figure 3) (Table 2). For ENF, vegetation activity was not sensitive to temperature change $(p>0.1)$; DNF and DBF initially responded positively to elevated temperatures, but soon afterwards reached a stable state, and are no longer responding positively to temperature changes. We argued that current temperatures are no longer a dominant constraint factor for these biomes, but fortunately no marked decrease in activity is occurring. In contrast, CRO photosynthetic activity has declined significantly since 1990. However, SAV, MF, SHR, WSA and GRA have responded significantly positively to elevated temperatures $(p<0.001)$. Perhaps climate warming is relaxing heat constraints on vegetation activity in these biomes.
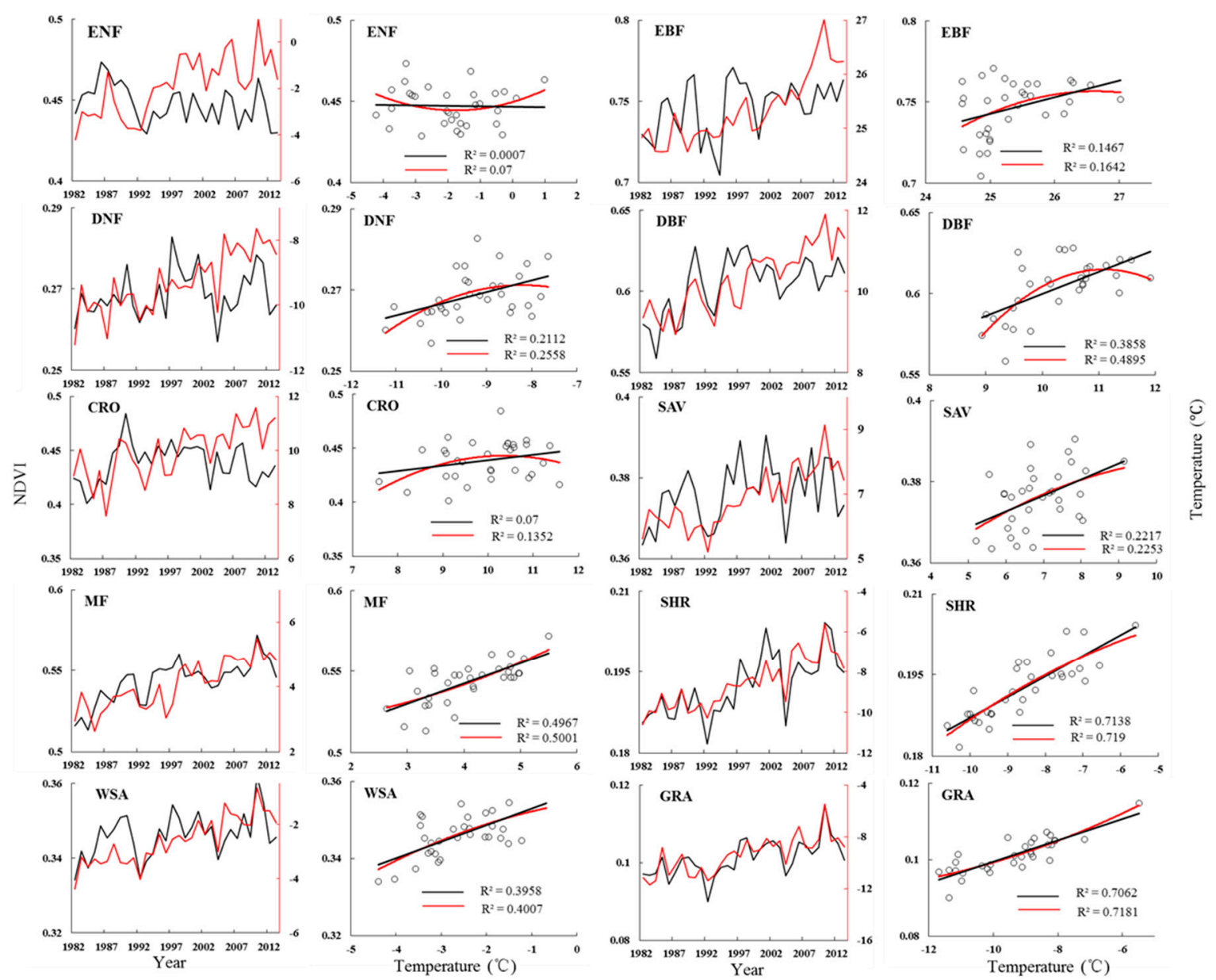

Figure 3. The dynamics of NDVI from 1982-2013 and the heat responses of NDVI to elevated temperatures (red line-quadratic function; black line-linear function) for various vegetation biomes.

Table 2. Significance levels ( $p$-value) for heat responses of NDVI to elevated temperatures $\left(P_{\text {linear }}\right.$-linear function; $P_{\text {quadratic }}$ - quadratic function) for various vegetation biomes.

\begin{tabular}{ccccccccccc}
\hline & ENF & EBF & DNF & DBF & MF & SHR & WSA & SAV & GRA & CRO \\
\hline$P_{\text {linear }}$ & 0.888 & 0.031 & 0.008 & $<0.001$ & $<0.001$ & $<0.001$ & $<0.001$ & $<0.001$ & $<0.001$ & 0.143 \\
$P_{\text {quadratic }}$ & 0.354 & 0.074 & 0.014 & $<0.001$ & $<0.001$ & $<0.001$ & $<0.001$ & 0.025 & $<0.001$ & 0.122 \\
\hline
\end{tabular}

\section{Discussion and Concluding Remarks}

Temperature is a dominant climatic factor in regulating the dynamics of vegetation biome activity $[11,13,19-23]$. To amplify the effect of elevated temperatures on vegetation activity within a diverse set of biomes, study sites were specifically selected with more significant increments in MAT. 
The study sites for the MF, SHR, WSA and GRA biomes, which responded positively to ongoing climate warming, mainly occurred in areas of high latitude $\left(>60^{\circ} \mathrm{N}\right)$ where the climate has undergone relatively greater warming [24]. Study sites for the EBF, SAV and CRO biomes, which occupied lower latitude $\left(<40^{\circ}\right)$ areas, had more inconsistent results. This suggests that climate warming, which occurs at non-uniform rates along latitudinal gradients, is relaxing the heat constraint on vegetation activity in high latitude areas, whereas for low latitude biomes the heat constraint has probably been fully released already.

Elevated temperature can increase evapotranspiration rates, drought and heat stress [13,14], which in turn might be expected to increase mortality in forest biomes [12]. However, examination of the selected study sites suggests that forest biomes are more resistant than crops to elevated temperatures, probably because of differences in vegetation structure [25]. As for crops, climate warming has already had serious impacts on their growth. Consistent with our findings, Teixeira et al. [26] also suggested that cropping areas at high latitudes, particularly between $40^{\circ} \mathrm{N}$ and $60^{\circ} \mathrm{N}$, were suffering heat stress. Accordingly, we emphasize the need to alleviate the impact of excess heat on crop production $[27,28]$. The grassland biome in the Arctic, mainly dominated by tundra [29], is also noteworthy. It has experienced more significant climate warming than other regions. Indeed, tundra may have the greatest positive response of all biomes on earth to climate warming, being vitalized by changes in phenology, enhanced vegetation activity and increased reproductive effort [30].

Currently, scientists are devoting significant efforts to exploring the relative contribution to the greening of the earth of the many factors in the natural and social systems. Here, we have shown that vegetation activity in areas of high latitude may be experiencing a heat-constraint relaxation process, whereas in low latitude areas heat constraints have probably been released already. Further studies are expected to systematically consider other influential factors such as water availability, radiation, and $\mathrm{CO}_{2}$ fertilization, as well as human disturbance, since all synergistically impact vegetation biome activity.

Acknowledgments: This project was supported by the Nanjing Institute of Geography and Limnology Cross-functional Innovation Teams (NIGLAS2016TD01), and the Natural Science Foundation of Jiangsu Province (BK20151060). We thank Ronald Briggs for editing the manuscript language.

Conflicts of Interest: The authors declare no conflict of interest.

\section{References}

1. Lobell, D.B.; Schlenker, W.; Costa-Roberts, J. Climate Trends and Global Crop Production since 1980. Science 2011, 333, 616-620. [CrossRef] [PubMed]

2. Mao, J.; Shi, X.; Thornton, P.E.; Hoffman, F.M.; Zhu, Z.; Myneni, R.B. Global latitudinal-asymmetric vegetation growth trends and their driving mechanisms: 1982-2009. Remote Sens. 2013, 5, 1484-1497. [CrossRef]

3. Parry, M.L. Climate Change 2007-Impacts, Adaptation and Vulnerability: Working Group II Contribution to the Fourth Assessment Report of the IPCC; Cambridge University Press: Cambridge, UK, 2007.

4. Zhu, Z.; Piao, S.; Myneni, R.B.; Huang, M.; Zeng, Z.; Canadell, J.G.; Ciais, P.; Sitch, S.; Friedlingstein, P.; Arneth, A. Greening of the Earth and its drivers. Nat. Clim. Chang. 2016, 6, 791-795. [CrossRef]

5. Zeng, Z.; Piao, S.; Li, L.; Zhou, L.; Ciais, P.; Wang, T.; Li, Y.; Lian, X.; Wood, E.F.; Friedlingstein, P.; et al. Climate mitigation from vegetation biophysical feedbacks during the past three decades. Nat. Clim. Chang. 2017, 7, 432-436. [CrossRef]

6. Cong, N.; Shen, M.; Piao, S.; Chen, X.; An, S.; Yang, W.; Fu, Y.; Meng, F.; Wang, T. Little change in heat requirement for vegetation green-up on the Tibetan Plateau over the warming period of 1998-2012. Agric. For. Meteorol. 2017, 232, 650-658. [CrossRef]

7. Braswell, B.H.; Schimel, D.S.; Linder, E.; Moore, B. The response of global terrestrial ecosystems to interannual temperature variability. Science 1997, 278, 870-872. [CrossRef] 
8. Tietjen, B.; Schlaepfer, D.R.; Bradford, J.B.; Lauenroth, W.K.; Hall, S.A.; Duniway, M.C.; Hochstrasser, T.; Jia, G.; Munson, S.M.; Pyke, D.A.; et al. Climate change-induced vegetation shifts lead to more ecological droughts despite projected rainfall increases in many global temperate drylands. Glob. Chang. Biol. 2017, 23, 2743-2754. [CrossRef] [PubMed]

9. Allen, C.D.; Macalady, A.K.; Chenchouni, H.; Bachelet, D.; McDowell, N.; Vennetier, M.; Kitzberger, T.; Rigling, A.; Breshears, D.D.; Hogg, E.H.; et al. A global overview of drought and heat-induced tree mortality reveals emerging climate change risks for forests. For. Ecol. Manag. 2010, 259, 660-684. [CrossRef]

10. Sterl, A.; Severijns, C.; Dijkstra, H.; Hazeleger, W.; Oldenborgh, G.J.V.; Broeke, M.V.D.; Burgers, G.; Hurk, B.V.D.; Leeuwen, P.J.V.; Velthoven, P.V. When can we expect extremely high surface temperatures? Geophys. Res. Lett. 2008, 35, 63-72. [CrossRef]

11. Zhao, M.S.; Running, S.W. Drought-Induced Reduction in Global Terrestrial Net Primary Production from 2000 through 2009. Science 2010, 329, 940-943. [CrossRef] [PubMed]

12. Myneni, R.B.; Keeling, C.D.; Tucker, C.J.; Asrar, G.; Nemani, R.R. Increased plant growth in the northern high latitudes from 1981 to 1991. Nature 1997, 386, 698-702. [CrossRef]

13. Nemani, R.R.; Keeling, C.D.; Hashimoto, H.; Jolly, W.M.; Piper, S.C.; Tucker, C.J.; Myneni, R.B.; Running, S.W. Climate-driven increases in global terrestrial net primary production from 1982 to 1999. Science 2003, 300, 1560-1563. [CrossRef] [PubMed]

14. Leone, A.; Perrotta, C.; Maresca, B. Plant tolerance to heat stress: Current strategies and new emergent insights. In Abiotic Stresses in Plants; Springer: Amsterdam, The Netherlands, 2003; pp. 1-22.

15. Xu, Y.; Zhan, C.; Huang, B. Heat shock proteins in association with heat tolerance in grasses. Int. J. Proteom. 2011, 2011, 1059-1062. [CrossRef] [PubMed]

16. Singh, R.P.; Prasad, P.V.V.; Sunita, K.; Giri, S.N.; Reddy, K.R. Influence of high temperature and breeding for heat tolerance in cotton: A review. Adv. Agron. 2007, 93, 313-385.

17. Walter, J.; Jentsch, A.; Beierkuhnlein, C.; Kreyling, J. Ecological stress memory and cross stress tolerance in plants in the face of climate extremes. Environ. Exp. Bot. 2013, 94, 3-8. [CrossRef]

18. Pinzon, J.E.; Tucker, C.J. A non-stationary 1981-2012 AVHRR NDVI3g time series. Remote Sens. 2014, 6, 6929-6960. [CrossRef]

19. Alward, R.D.; Detling, J.K.; Milchunas, D.G. Grassland vegetation changes and nocturnal global warming. Science 1999, 283, 229-231. [CrossRef] [PubMed]

20. Bai, Y.; Han, X.; Wu, J.; Chen, Z.; Li, L. Ecosystem stability and compensatory effects in the Inner Mongolia grassland. Nature 2004, 431, 181-184. [CrossRef] [PubMed]

21. Cleland, E.E.; Chuine, I.; Menzel, A.; Mooney, H.A.; Schwartz, M.D. Shifting plant phenology in response to global change. Trends Ecol. Evol. 2007, 22, 357-365. [CrossRef] [PubMed]

22. Körner, C.; Basler, D. Phenology under global warming. Science 2010, 327, 1461-1462. [CrossRef] [PubMed]

23. Yang, Y.; Fang, J.; Ma, W.; Wang, W. Relationship between variability in aboveground net primary production and precipitation in global grasslands. Geophys. Res. Lett. 2008, 35, L23710. [CrossRef]

24. Mao, J.; Ribes, A.; Yan, B.; Shi, X.; Thornton, P.E.; Séférian, R.; Ciais, P.; Myneni, R.B.; Douville, H.; Piao, S.; et al. Human-induced greening of the northern extratropical land surface. Nat. Clim. Chang. 2016, 6, 959-963. [CrossRef]

25. Huxman, T.E.; Smith, M.D.; Fay, P.A.; Knapp, A.K.; Shaw, M.R.; Loik, M.E.; Smith, S.D.; Tissue, D.T.; Zak, J.C.; Weltzin, J.F.; et al. Convergence across biomes to a common rain-use efficiency. Nature 2004, 429, 651-654. [CrossRef] [PubMed]

26. Teixeira, E.I.; Fischer, G.; van Velthuizen, H.; Walter, C.; Ewert, F. Global hot-spots of heat stress on agricultural crops due to climate change. Agric. For. Meteorol. 2013, 170, 206-215. [CrossRef]

27. Asseng, S.; Foster, I.; Turner, N.C. The impact of temperature variability on wheat yields. Glob. Chang. Biol. 2011, 17, 997-1012. [CrossRef]

28. Long, S.P.; Ort, D.R. More than taking the heat: Crops and global change. Curr. Opin. Plant Biol. 2010, 13, 241-248. [CrossRef] [PubMed] 
29. Olson, D.M.; Dinerstein, E.; Wikramanayake, E.D.; Burgess, N.D.; Powell, G.V.; Underwood, E.C.; D'amico, J.A.; Itoua, I.; Strand, H.E.; Morrison, J.C. Terrestrial Ecoregions of the World: A New Map of Life on Earth A new global map of terrestrial ecoregions provides an innovative tool for conserving biodiversity. Bioscience 2001, 51, 933-938. [CrossRef]

30. Hollister, R.D.; Webber, P.J.; Bay, C. Plant response to temperature in Northern Alaska: Implications for predicting vegetation change. Ecology 2005, 86, 1562-1570. [CrossRef] 